\title{
Lower Carboniferous ostracodes from the Maritimes Basin of eastern Canada:
} A review

\author{
Chris Dewey \\ Department of Geology and Geography, Drawer 5167, Mississippi State University \\ Mississippi 39762, U.S.A.
}

Date Received May 25, 1988

Date Accepted August 15, 1988

\begin{abstract}
Lower Carboniferous ostracode assemblages of marine affinity occur in sediments of the Codroy Group in southwestern Newfoundland and the Windsor Group in central Nova Scotia. Three ostracode assemblages are defined from Nova Scotia and five from Newfoundland. The assemblages are described from biohermal and non-biohermal limestones and fine-grained siliciclastic lithologies. The assemblages can be characterised by their responses to varying degrees of physiological stress, and are dominated by members of the Paraparchitacea, although bairdiaceans, hollinomorph and kirkbyacean palaeocopids and kloedenellaceans may be locally abundant.

In the Maritimes Basin, the combined effects of tectonism, eustatic fluctuation and a semi-arid climate resulted in palaeoenvironments that were characterised by low temporal and spatial stability. As a consequence, total ostracode species richness relative to individual species abundances was low, and often expressed in the development of low grade communities that were controlled more by physical (allogenic) rather than biological (autigenic) parameters. Under these conditions the eurytopic paraparchitaceans were capable of producing large populations in physically harsh palaeoenvironments, whereas the more stenotopic bairdiaceans and palaeocopes only occurred when conditions were favourable.
\end{abstract}

Les sédiments des groupes de Codroy (sud-ouest de Terre-Neuve) et de Windsor (centre de la Nouvelle-Ecosse) renferment des assemblages d'Ostracodes, à affinité marine, du Carbonifêre inférieur. On reconnaît trois assemblages en Nouvelle-Ecosse et cinq à Terre-Neuve. Ces assemblages proviennent de calcaires (biohermaux ou non) et de lithologies siliciclastiques à grain fin. On peut caractériser ces assemblages par leurs réponses aux divers degrés de stress physiologique. On y note la prédominance des représentants des Paraparchitacea mal gré l'abondance locale des bairdiacés, des paléocopidés hollinomorphes et kirkbyacés ainsi que des kloedenellacés.

Dans le Bassin des Maritimes, la conjonction de divers facteurs (tectonisme, fluctuations eustatiques, climat semi-aride) se traduisit par des paléomilieux caractérisés par une stabilité spatiale et temporelle faible. En conséquence, la richesse spécifique totale des Ostracodes était basse par rapport aux abondances spécifiques individuelles et s'exprimait souvent part le développement de communautés immatures contrôlées par des paramètres plus physiques (allogènes) que biologiques (autogènes). Dans ces conditions, les paraparchitacés eurytopiques pouvaient peupler abondamment les paléomilieux physiquement exigeants, alors que les bairdiacés et les paléocopes (qui étaient plus sténotopiques) n'étaient présents que dans des biotopes favorables.

[Traduit par le joumal]

\section{INTRODUCTION}

During the lower Carboniferous, the Maritimes Basin was an evolving, strike-slip basin (Bradley, 1982; Knight, 1983), which was subdivided into a number of subbasins separated by arches (Howie and Barss, 1975). For most of its depositional history (from late Devonian to late Carboniferous), the Maritimes Basin and its constituent subbasins, was a fluvial depocentre. Transgressive marine inundation of the basin occurred during deposition of the Windsor Group of Nova Scotia (Bell, 1929; Giles, 1981) and the Codroy Group of Newfoundland (Bell, 1948; Baird and Cote, 1964; Knight, 1983), (Fig. 1). During the transgressive episodes the Maritimes Basin was an epicontinental embayment of the northern Hercynian Ocean (Dewey, 1985).
The occurrence of red siliciclastics, evaporites, limestones and coals within the basin suggests an arid to semi-arid climate (Bell, 1929; Schenk, 1969; Van de Poll, 1978; Van der Zwan, 1981), which, together with the effects of eustacy and tectonism resulted in a broad range of palaeoenvironments. Non-marine deposition occurred in alluvial fan, fluvial and lacustrine settings. Coastal palaeoenvironments included deltaic, brackish marginal-marine and hypersaline sabkhas. Marine conditions are represented by nearshore, open and restricted palaeoenvironments as well as biohermal settings. The ostracodes which form the focus of this study are described from a variety of siliciclastic and carbonate, marine and near-marine palaeoenvironments. 


\begin{tabular}{|c|c|c|c|c|c|c|c|c|}
\hline \multicolumn{2}{|c|}{ U. S. A. } & \multicolumn{4}{|c|}{$C A N A D A$} & \multicolumn{3}{|c|}{ U. K. } \\
\hline \multirow{2}{*}{$\frac{E}{0}$} & \multirow{2}{*}{ 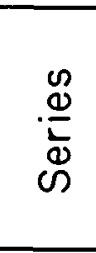 } & \begin{tabular}{|c|}
$\begin{array}{c}\text { Faunal } \\
\text { Subzones }\end{array}$ \\
Bell \\
\end{tabular} & $\begin{array}{l}\text { NOVA SCOTIA } \\
\text { Minas Subbasin }\end{array}$ & \multicolumn{2}{|c|}{$\begin{array}{l}\text { NEWFOUNDLAND } \\
\text { St. George's Bay Subbasin }\end{array}$} & \multirow{2}{*}{$\stackrel{8}{\stackrel{8}{0}}$} & \multirow{2}{*}{$\stackrel{\mathscr{\Xi}}{\bar{\Phi}}$} & \multirow{2}{*}{ 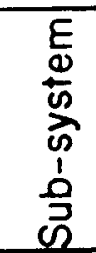 } \\
\hline & & \begin{tabular}{|c|} 
Bell \\
1927,1929 \\
\end{tabular} & $\begin{array}{c}\text { Giles et al. } 1979 \\
\text { Giles } 1981\end{array}$ & S.W. Knight $1983 \quad$ N.E. & \begin{tabular}{|l|} 
Baird and \\
Coté 1964
\end{tabular} & & & \\
\hline \multirow{5}{*}{ 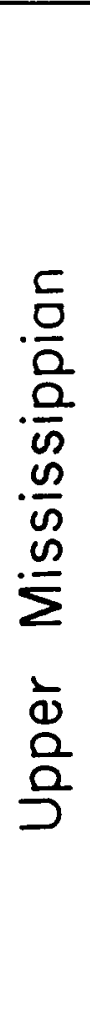 } & \multirow{5}{*}{ 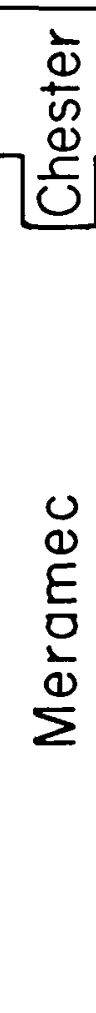 } & \multirow{5}{*}{ 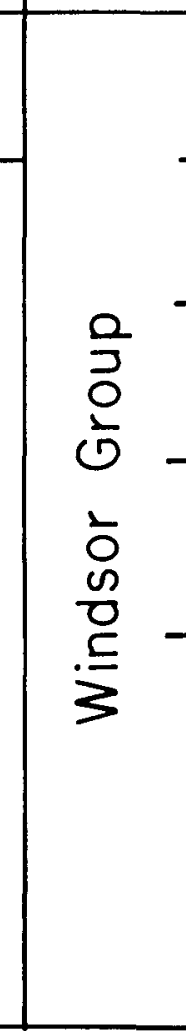 } & \multirow[t]{2}{*}{ Green Oaks } & \multirow{3}{*}{$\begin{array}{l}\text { Rormation } \\
\text { Roody Cape } \\
\text { Formation } \\
\text { Robinsons } \\
\mathrm{C} / \mathrm{J}= \\
\mathrm{N}=\end{array}$} & \multirow{2}{*}{ 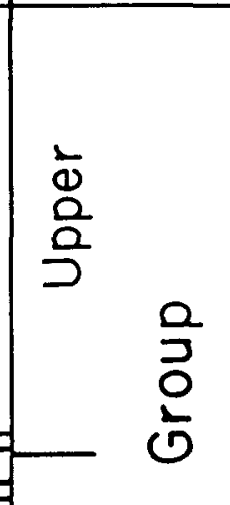 } & 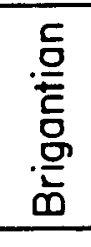 & \multirow{5}{*}{ 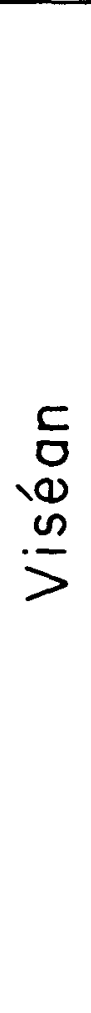 } & \multirow{5}{*}{ 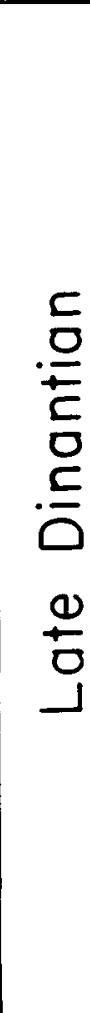 } \\
\hline & & & & & & $\frac{.5}{0}$ & & \\
\hline & & & $=\begin{array}{c}=D, P \quad \text { Macdonald Road } \\
\text { Formation }\end{array}$ & & \multirow{3}{*}{ 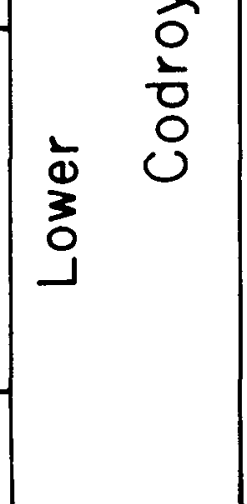 } & & & \\
\hline & & & $\sqrt[5]{\text { Corner Formation }}$ & $\begin{array}{l}\text { Codroy Road } \\
\text { Formation }\end{array}$ & & \multirow[t]{2}{*}{ 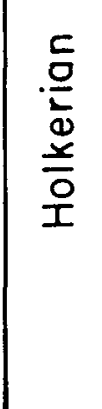 } & & \\
\hline & & & $\begin{array}{l}\text { Macumber and Gays } \\
\text { River Formations }\end{array}$ & Ship Cove Formation & & & & \\
\hline & & D, P: Dimoc & $\begin{array}{l}\text { K: Kennetcook Limestone } \\
\text { k \& Phillips Limestones }\end{array}$ & $\begin{array}{l}\mathrm{C} / \mathrm{J}: \text { Crabbes/Jeffreys Lime } \\
\mathrm{N}: \text { Nodosinella Band }\end{array}$ & stone & & & \\
\hline
\end{tabular}




\section{HISTORY OF STUDY}

The first reference to Carboniferous ostracodes in the Maritimes Basin was by Dawson (1868) in the second edition of "Acadian Geology." In 1879, Dawson published a note on some ostracodes in the Peter Redpath Museum that had been described by Jones and Kirkby. Jones and Kirkby (1884) followed the note with descriptions of ostracodes from Nova Scotia that had been sent to them by Dawson from the Horton Group and from the coal measures at Joggins. These data, together with further descriptions of Carbonita from the Mabou Coal Field on Cape Breton Island (Jones and Kirkby, 1889), form the basis of ostracode study in the Maritimes Basin. Bell (1929) described the first ostracodes from Windsor Group sediments of Nova Scotia, and described some more material from the Horton Group (Bell, 1960). Copeland (1957) described an extensive, predominantly freshwater ostracode fauna from the Canso, Riversdale, Cumberland and Pictou Groups in Nova Scotia; and Bless and Jordan (1971) erected a new genus, Copelandella, in a re-description of material from the Horton Group. Dewey (1983a), provided the first detailed taxonomic and palaeoecological study of marine ostracodes in the lower Carboniferous strata of the Maritimes Basin.

Samples for ostracode analysis (Dewey, 1983a) were collected from lower Carboniferous strata in five areas of southwestem Newfoundland and central Nova Scotia (Fig. 2). The samples were collected from limestones and shales that represent marine and near-marine conditions within the basin. Discussions of the Newfoundland ostracodeassemblagesare given in Dewey (1983b) and the Nova Scotia assemblages are described in Dewey (1987, 1988). This paper presents a regional palaeoecological synthesis of these data using the taxonomy in Dewey and Fahraeus (1987).

\section{CARBONIFEROUS OSTRACODE PALAEOECOLOGY}

Ostracodes have been used widely to determine distance from shore, bathymetry and conditions of palaeosalinity in Carboniferous palaeoenvironments. At least three distinct types of ostracode fauna existed during late Palaeozoic time, (van Ameron et al., 1970; Becker, 1980; Bless, 1983): (i) Carbonita-type faunas, indicative of freshwater conditions (Pollard, 1966; Bless and Pollard, 1973),(ii) Entomozoacean-Tricorninid-type faunas, indicative of deep basinal environments (Becker et al., 1975; Becker, 1982, 1984), including the "ecotype de Thuringe" of Lethiers and Crasquin (1987), and (iii) Paraparchitacean, bairdiacean, palaeocope and kloedenellacean faunas, indicative of a range of environments from marginal marine to outer shelf. An extensive literature exists concerning the distribution of these types of faunas (see for example: van Ameron et al., 1970; Becker et al., 1974; Haack and Kaesler, 1980; Kaesler, 1982; Bless, 1983; Crasquin, 1984; Melnyk and Maddocks, 1988). Comprehensive studies that evaluate the ecological tolerance and significance of individual genera and species are however, few.

The study of ostracode faunas from the Maritimes Basin provides an opportunity to examine the distribution of "shallow marine" faunas in a variety of palaeoenvironments that were associated with varying degrees of physiological stress.

\section{NOVA SCOTIAN ASSEMBLAGES}

Ostracodes were collected from three transgressive marine carbonate units within the Windsor Group. Ostracodes were collected from a biostromal limestone in the Gays River Formation in Antigonish County, from carbonate-siltstone-evaporite triplets in a lateral equivalent of the MacDonald Road Formation in Hants County and from the Kennetcook Limestone in the uppermost Green Oaks Formation of Hants County (Figs. 1, 2). (For detailed sampling data refer to Dewey, 1983a or Dewey and Fahraeus, 1987.)

\section{Assemblage A}

This assemblage (Table 1) was derived from a massive, buffcoloured, micritic limestone in the Gays River Formation in Antigonish County (Dewey, 1988). The bioclastic association developed over a drowned granodioritic pluton, which acted as a topographic high during the first marine transgression of Windsor time (Geldsetzer et al., 1980). A varied invertebrate fauna consists of ostracodes, brachiopods, bryozoans, conulariids, bivalves and gastropods, but corals and crinoids are notably absent. Nine species of ostracode are present, of which $75 \%$ of the individuals are represented by the paraparchitaceans Chamishaella suborbiculata (Munster, 1830) and Shishaella moreyi Sohn, 1971. Bairdiaceans form only about $10 \%$ of the ostracode fauna and the only palaeocope present is Amphissites sp. aff. $A$. centronotus (Ulrich and Bassler, 1906), which represents 3\% of the fauna. Paraparchitaceans have been described from nearshore marine environments of various salinities (Sohn, 1971; van Ameron et al., 1970; Robinson, 1978; Bless, 1983), whereas bairdiaceans are only recorded from stable, shallow, subtidal, normal marine salinity environments (Kornicker, 1961; Ferguson, 1962, 1974; Kaesler, 1982; Crasquin, 1984). The ostracode association suggests a shallow marine shelf environment; however, the lack of corals or crinoids together with the overlying evaporites that occur throughout the area, also suggest an abnormally saline environment. Ostracode assemblage $A$ is contemporaneous with Newfoundland Assemblages I and II (Dewey, 1983b).

\section{Assemblage B}

This assemblage (Table 1) was collected from the dark brown, micritic, Dimock and Phillips Limestones (Fig. 1) in Hants County (Dewey, 1987, 1988). The limestones contain a very high abundance, low diversity fauna of ostracodes, rare brachiopods and the ?bryozoan Palaeocrisidia. The Dimock and Phillips Limestones each occur at the base of a carbonatesiltstone-evaporite triplet. The evaporites developed on supratidal sabkhas and the limestones represent marginal marine conditions (Geldsetzer et al., 1980). The ostracode fauna consists of only five species, of which more than $75 \%$ is composed of Paraparchites sp. aff.P. kellettae Sohn, 1971 and Chamishaella suborbiculata. The sedimentological evidence (Geldsetzer $e t$ al., 1980) supports the idea that high abundances of paraparchitaceans may be related to salinity-stressed environments (Sohn, 


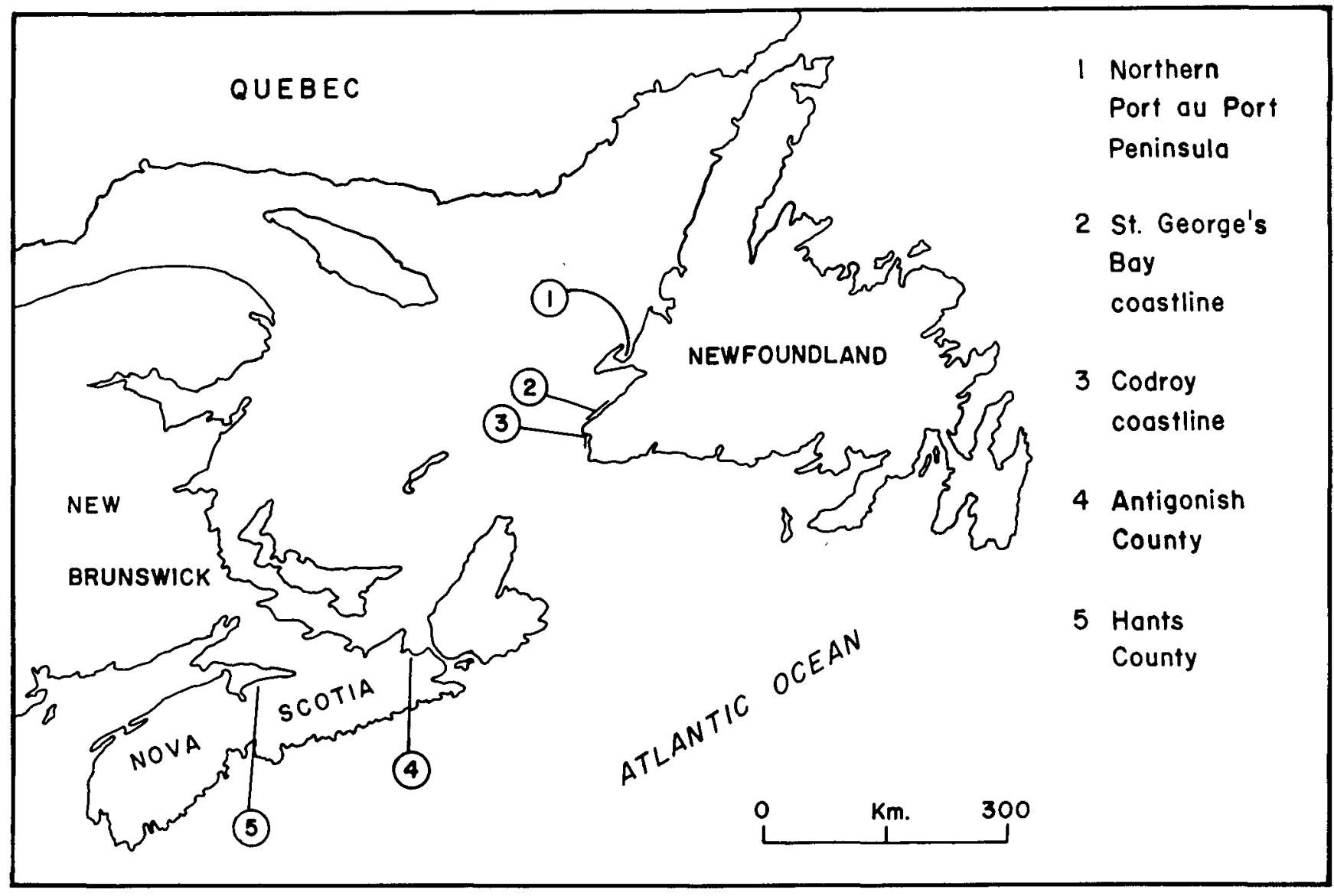

Fig. 2. Location of study area.

1971; Robinson, 1978; Bless, 1983; Dewey, 1987). A further $20 \%$ of the fauna is composed of Beyrichiopsis lophota Copeland, 1957. Beyrichiopsis is thought to be an indicator of marginal marine environments (Becker et al., 1974) and its occurrence in Nova Scotian materials (Copeland, 1957; Dewey, 1987) may indicate a broad salinity tolerance in such environments. Growth curves for Paraparchites sp. aff. P. kellettae and B. lophota indicate that the assemblage is an in situ, multi-generation fauna, and that Paraparchites sp. aff. $P$. kellettae exhibits progenic parthenogenesis (Dewey, 1987). The ostracode fauna is typical of a low level community and the very large populations of a few species probably reflects a lack of inter-specific competition due to the exclusion of stenotopic specialists, rather than a nutrient rich environment (Levinton, 1970). The assemblage is therefore interpreted as occurring in a nearshore hypersaline carbonate environment where opportunistic euryhaline species could thrive in abundance whereas less tolerant species were unable to survive.

\section{Assemblage C}

This assemblage (Table 1) was derived from the massively bedded, buff-coloured bioclastic Kennetcook Limestone (Fig. 1) in Hants County (Dewey, 1988). The limestone contains a rich fauna of brachiopods, gastropods, bivalves, bryozoans, corals, tentaculitids, crinoid ossicles, forams and twelve species of ostracodes. The sedimentologic and faunal evidence suggests a low energy, shallow subtidal environment of near normal marine salinity (Moore, 1967).

The dominant ostracodes in this assemblage are members of the Subfamily Bairdiinae, which, represented by Bairdia brevis Jones and Kirkby, 1867, Bairdia sp. L. Sohn, 1960 and Bairdiacypris quartziana Egorov, 1953 constitute $42 \%$ of the fauna. A co-dominant group is the Palaeocopida which accounts for $37 \%$ of the fauna. The most common palaeocope is Kirkbya novascotica Dewey and Fahraeus, 1987 although rare individuals of "Gortanella" sp. are also present. The association of bairdiaceans and kirkbyaceans in Late Palaeozoic faunas indicates stable, offshore, normal marine salinity environments (van Ameron et al., 1970; Becker et al., 1974; Kaesler, 1982).

The assemblage does not exhibit a high species diversity, but the presence of corals, crinoids and forams would suggest that salinity-stress was not a factor in determining the assemblage composition.

\section{NEWFOUNDLAND ASSEMBLAGES}

Ostracodes occur in marine and near-marine carbonate and siliciclastic sediments of the Codroy Group (Fig. 1). Ostracodes were collected from a biohermal limestone and grey micrites in the Ship Cove Formation, from limestone and shale in the lower part of the Robinsons River Formation and from dark shale within the Woody Cape Formation. (For detailed sampling locations see Dewey, 1983a or Dewey and Fahraeus, 1987). 
Table 1. Distribution of ostracodes in marine assemblages of the Windsor and Codroy Groups.

\begin{tabular}{|c|c|c|c|c|c|c|c|c|}
\hline \multirow[b]{3}{*}{ OSTRACODE SPECIES } & \multicolumn{7}{|c|}{ ASSEMBLAGE } & \\
\hline & \multicolumn{3}{|c|}{ NOVA SCOTIA } & \multicolumn{5}{|c|}{ NEWFOUNDLAND } \\
\hline & A & B & $\mathrm{C}$ & I & II & III & IV & V \\
\hline "Copelandella" sp. & & & & & & $\mathbf{x}$ & & $\mathbf{x}$ \\
\hline Gortanella sp. & & & $\mathbf{x}$ & & & & $\mathbf{x}$ & \\
\hline $\begin{array}{l}\text { Aechmina sp. } \\
\text { Kirkbya novascotica Dewey }\end{array}$ & & & $\mathbf{x}$ & $\mathbf{x}$ & & & & \\
\hline $\begin{array}{l}\text { Kirkbya novascollca Lewey } \\
\text { and Fahraeus, } 1987\end{array}$ & & & $\mathbf{x}$ & & & & & \\
\hline $\begin{array}{l}\text { Amphissites (Amphidites) } \\
\text { aguathunaensis Dewey and }\end{array}$ & & & & $\mathbf{x}$ & & & & \\
\hline Fahraeus, 1987 & & & & & & & & \\
\hline $\begin{array}{l}\text { Amphissites sp. aff. A. } \\
\text { centronotus (Ulrich and } \\
\text { Bassler, 1906) }\end{array}$ & $\mathbf{x}$ & & & & $?$ & & & \\
\hline Youngiella sp. & & & & $\mathbf{x}$ & $\mathbf{x}$ & & & \\
\hline Bairdia sp. L. Sohn, 1960 & $\mathbf{x}$ & & $\mathbf{x}$ & $\mathbf{x}$ & & & & \\
\hline $\begin{array}{l}\text { Bairdia brevis Jones and } \\
\text { Kirkby, } 1867\end{array}$ & & & $\mathbf{x}$ & & & & & \\
\hline Bairdiacypris quartziana & & & $\mathbf{x}$ & & & & & \\
\hline Egorov, 1953 & & & & & & & & \\
\hline Bairdiacypris striatiformis & & & & $\mathbf{x}$ & $\mathbf{x}$ & & & \\
\hline Dewey and Fahraeus, 1987 & & & & & & & & \\
\hline $\begin{array}{l}\text { Acratia acuta (Jones and } \\
\text { Kirkby, 1895) }\end{array}$ & $\mathbf{x}$ & $\mathbf{x}$ & $\mathbf{x}$ & $\mathbf{x}$ & $\mathbf{x}$ & $\mathbf{x}$ & $\mathbf{x}$ & \\
\hline Acratia sp. A. & & & & $\mathbf{x}$ & & & & \\
\hline Acratia sp. B. & & & & $\mathbf{x}$ & & & & \\
\hline $\begin{array}{l}\text { Bythocypris aequalis } \\
\text { Jones and Kirkby, } 1886\end{array}$ & $\mathbf{x}$ & $\mathbf{x}$ & $\mathbf{x}$ & & & $\mathbf{x}$ & & $\mathbf{x}$ \\
\hline $\begin{array}{l}\text { Monoceratina antiqua } \\
\text { (Jones and Kirkby, 1886) }\end{array}$ & & & & $\mathbf{x}$ & & & & \\
\hline $\begin{array}{l}\text { Monoceratina youngiana } \\
\text { (Jones and Kirkby, 1886) }\end{array}$ & & & $\mathbf{x}$ & & & & & \\
\hline Geisina sp. & & & & & & $\mathbf{x}$ & & $\mathbf{x}$ \\
\hline Beyrichiopsis cornuta & & & $\mathbf{x}$ & & & & & \\
\hline Jones and Kirkby, 1886 & & & & & & & & \\
\hline $\begin{array}{l}\text { Beyrichiopsis lophota } \\
\text { Copeland, } 1957\end{array}$ & & $\mathbf{x}$ & & & & & & \\
\hline Sulcella levisulcata & $x$ & & & $\mathbf{x}$ & $\mathbf{x}$ & $\mathbf{x}$ & & $\mathbf{x}$ \\
\hline Dewey and Fahraeus, 1987 & & & & & & & & \\
\hline Healdia sp. & & & & $\mathbf{x}$ & & & & \\
\hline Healdianella sp. & $\mathrm{x}$ & & $\mathbf{x}$ & $\mathbf{x}$ & & & & \\
\hline $\begin{array}{l}\text { Paraparchites sp. aff. } P . \\
\text { kellettae Sohn, } 1971\end{array}$ & & $\mathbf{x}$ & & & & & & \\
\hline $\begin{array}{l}\text { Chamishaella suborbiculata } \\
\text { (Munster, 1830) }\end{array}$ & $\mathbf{x}$ & $\mathbf{x}$ & $\mathbf{x}$ & $\mathbf{x}$ & $\mathrm{x}$ & $\mathbf{x}$ & $\mathbf{x}$ & $\mathrm{x}$ \\
\hline $\begin{array}{l}\text { Chamishaella inverticoriformis } \\
\text { Dewey and Fahraeus, } 1987\end{array}$ & & & & $\mathbf{x}$ & $\mathbf{x}$ & $\mathbf{x}$ & & \\
\hline $\begin{array}{l}\text { Shemonaella scotoburdigalensis } \\
\text { (Hibbert, 1836) }\end{array}$ & & & & $\mathbf{x}$ & & & & $x$ \\
\hline Shishaella moreyi Sohn, 1975 & $\mathbf{x}$ & & & $\mathbf{x}$ & $\mathbf{x}$ & & & \\
\hline Shivaella sp. & & & & $\mathrm{x}$ & $\mathbf{x}$ & & & \\
\hline $\begin{array}{l}\text { Polycope spinula Dewey and } \\
\text { Fahraeus, } 1987\end{array}$ & $\mathbf{x}$ & & $\mathbf{x}$ & $\mathbf{x}$ & & & & \\
\hline
\end{tabular}




\section{Assemblage I}

This is the most species-rich assemblage of the present study (Table 1) and is based upon samples from a buff-coloured, biohermal limestone that infilled a karsted terrain on the northern Port au Port Peninsula (Fig. 2). The assemblage is dominated by smooth and spinose paraparchitaceans, which as a group comprise more than $80 \%$ of the ostracode fauna and include $\mathrm{Cha}$ mishaella suborbiculata, $C$. inverticoriformis Dewey and Fahraeus, 1987, Shemonaella scotoburdigalensis (Hibbert, 1836), Shishaella moreyi, and rare Shivaella sp. The species $C$. suborbiculata dominates, and contributes ten times more individuals to the assemblage than any other single species. Bairdiaceans, including three species of Acratia together with Bairdia sp. $L$, and Bairdiacypris striatiformis Dewey and Fahraeus, 1987 as well as a kirkbyacean, Amphissites (Amphidites) aguathunaensis Dewey and Fahraeus, 1987, are indicative of shallow shelf conditions.

A subassemblage, derived from plant-bearing sandstones associated with the biohermal limestones, includes a few individuals of $C$. suborbiculata and $S$. moreyi together with Acratia acuta (Jones and Kirkby, 1895).

The biohermal ostracode fauna, together with the high abundance, low diversity macro-invertebrate fauna dominated by bryozoans, brachiopods and microbial communities, but lacking in echinoderms and corals (Dix, 1982; Dix and James, 1987), is suggestive of environmental salinity stress. Dix (1982), and Dix and James (1987) suggest that the associated plantbearing sandstones were deposited by the episodic influx of sediment-laden fresh-water, which therefore lowered the local salinity. During calm weather when fluvial influx was minimal, hypersaline conditions may have developed (Dix and James, 1987). It is possible therefore, that the paraparchitacean-dominated faunas of Assemblage I are a result of fluctuating salinities, rather than raised or lowered salinities per se.

An alternative suggestion for carbonate mound development in the lower Codroy Group of the Port au Port Peninsular, is that they developed as hydrothermal vent associations (von Bitter $e t$ al., 1988). In this case, it is unlikely that salinity would play such an important role in determining the nature of the biotic associations. The vent association model would explain the lack of calcareous algae (Dix and James, 1987), the "large ?worm tubes" (Dix, 1982) and also the sulphide and sulphate mineralisation (Dix, 1982; von Bitter et al., 1988). The model would also represent a unique occurrence for Carboniferous ostracode faunas.

This assemblage is contemporaneous with Assemblage II and Nova Scotia Assemblage A.

\section{Assemblage II}

This assemblage (Table 1) is laterally equivalent to Assemblage I and occurs on the northem Port au Port Peninsula in an eight-metre sequence of grey, laminated, peloidal micrites containing solution collapse features. The upper units of the section have a lower ostracode diversity than the lower units and contain C. suborbiculata, S. moreyi, Shivaella sp. and A. acuta. In addition to these, the lower units contain Youngiella sp., a poorly preserved species of Amphissites, and Sulcella levisulcata Dewey and Fahraeus, 1987, all of which occur in similar proportions. The assemblage shows a progressive reduction in both diversity and individual abundances, from the base to mid section and then diversity begins to increase again, though not to the initial levels (Dewey, 1983a). Dix (1982) suggests that the depositional environment was a broad, shallow, hypersaline basin. The paraparchitacean-dominated ostracode fauna indicates that the basin never had truly normal marine salinity waters within it, and furthermore, that the palaeoenvironmental conditions deteriorated progressively after the initial transgression and then improved slightly during deposition of the uppermost units.

\section{Assemblage III}

This assemblage (Table 1) occurs in the grey shales of the Nodosinella Band (Fig. 1) in the region of the St. George's Bay coastline (Fig. 2). The assemblage is derived from units equivalent to Lithofacies M of the Robinsons River Formation (Knight, 1983). The shales are interpreted as being deposited in a restricted marine environment such as a back-barrier lagoon that was subject to occasional high energy deposition and variations in salinity (Knight, 1983). The ostracode fauna is relatively sparce, although some samples do show high abundances (Dewey, 1983a). C. suborbiculata, A. acuta and S. levisulcata, occur in almost equal proportions although Chamishaella still dominates. Geisina sp. and "Copelandella" are rare components of the assemblage that do not occur in Assemblage I or II. Pollard (1969) suggested a brackish-water affinity for Geisina, and Bless and Jordan (1971) stated that Copelandella is a nearshore marine form that might occur in brackish or even fresh water. The low diversity of the paraparchitacean-dominated ostracode fauna, coupled with the occurrence of a few individuals of brackish species, suggests that this assemblage also developed under conditions of varying salinity.

\section{Assemblage IV}

Ostracodes of Assemblage IV (Table 1) occur sparsely in the shaley limestones of the Crabbes-Jeffreys Limestone (Fig. 1). The Crabbes-Jeffreys limestone is equivalent to Lithofacies $R$ of the Robinsons River Formation (Knight, 1983). The sparse ostracode assemblage includes $C$. suborbiculata, $A$. acuta and "Gortanella" sp. The presence of the hollinomorph "Gortanella" sp., is indicative of stable, normal marine salinity conditions. The absence of Bairdia is significant, however a nearshore marine association characterised by the presence of velate palaeocopes but lacking in bairdiaceans has been proposed by several authors (von Ameron et al., 1970; Kaesler, 1982). Due to the small numbers of individuals present, it is not certain whether the assemblage is in situ.

\section{Assemblage V}

The grey and black shales of the Woody Cape Formation in the Codroy coastline area (Fig. 2) occur within what is interpreted 
to be a deltaic sequence (Knight, 1983) and yield few ostracodes. C. suborbiculata is still the most common form, but is associated with Geisina sp. and "Copelandella" sp. The ostracodes associated with the Woody Cape Formation are indicative of restricted marginal marine conditions. The presence of Geisina and "Copelandella" may indicate brackish salinity.

\section{DISCUSSION}

Ostracodes from lower Carboniferous strata of the Maritimes Basin occur in a variety of palaeoenvironments. Nova Scotia Assemblage $\mathrm{C}$ is dominated by bairdiaceans and kirkbyaceans and can therefore be considered to represent normal marine salinity, offshore, shelf conditions. Newfoundland Assemblage IV, contains hollinomorphs but no bairdiaceans and may be indicative of nearshore stable marine conditions.

All other assemblages are paraparchitacean-dominated. Nova Scotia Assemblage B and Newfoundland Assemblage II can be related to coastal hypersaline conditions and therefore indicate that paraparchitaceans were tolerant of raised salinities. Furthermore, in such palaeoenvironments the paraparchitaceans often produced large populations and behaved as opportunists. The occurrence of B. lophota in Nova Scotia Assemblage B indicates that this form, typically associated with brackish palaeoenvironments, exhibited a euryhaline tolerance.

Newfoundland Assemblages III and V are harder to evaluate. The abundance of paraparchitaceans and their association with brackish water indicators such as Geisina and "Copelandella" suggests a tolerance for a wide range of salinities. The scarcity of both Geisina and "Copelandella" in these assemblages may be a function of short-lived or unstable palaeoenvironments, whereas paraparchitaceans such as Chamishaella suborbiculata were capable of withstanding these conditions.

Nova Scotia Assemblage A is also paraparchitacean-dominated, but contains some bairdiaceans and a kirkbyacean, which may indicate an affinity to offshore marine conditions. The paraparchitacean dominance, given other associations demonstrated herein, is taken to indicate raised salinities. Of related interest is Newfoundland Assemblage I which contains a similar, but higher diversity fauna, and occurs in a biohermal association that also developed in a salinity-stressed palaeoenvironment. The contemporaneous development of Nova Scotia Assemblage A and Newfoundland Assemblages I and II in three different palaeoenvironments, during the first transgression of Windsor/ Codroy time, coupled with the abundance of paraparchitaceans in all three assemblages, might indicate that the transgressive waters were not of normal marine salinity.

A new idea (von Bitter et al., 1988) is that during the first marine transgression into the Maritimes Basin, the "Windsor Sea" contained numerous, ephemeral, hydrothermal vents which controlled both the depositional styles and biotic associations of early Windsor/Codroy time (von Bitter et al., 1988).

\section{SUMMARY}

Ostracode assemblages from marine and near-marine palaeoenvironments of the Windsor and Codroy Groups reveal much about the nature of Late Palaeozoic ostracode palaeoecology: (i) In keeping with previous studies, the occurrence of bairdiaceans and kirkbyaceans in significant numbers is indicative of offshore, normal marine salinity conditions; (ii) also, that a velate palaeocope (hollinomorph) fauna, devoid of bairdiaceans, occurs in nearshore, normal marine salinity conditions. (iii) Paraparchitaceans are ubiquitous, can exhibit a wide tolerance to salinity and may behave as opportunists in palaeoenvironments where salinity-stress restricts the occurrence of stenohaline normal marine forms. (iv) Large populations of paraparchitaceans resulting in the domination of an ostracode assemblage, may be taken as indicative of either raised or fluctuating salinities. (v) An anti-pathetic relationship can exist between the bairdiaceans and paraparchitaceans, which, in the Maritimes Basin is a function of competitive ability and ecological tolerance. This is in contrast to the development of a bairdiaceanparparchitacean ecozone in other areas of stable carbonate shelf sedimentation (Crasquin, 1984). (vi) Brackish water indicators such as the kloedenellaceans Geisina and Beyrichiopsis and the beyrichiomorph Copelandella may be tolerant of raised salinities, but rarely produce large populations in such environments.

BAIRD, D.M. and COTE, P.R. 1964. Lower Carboniferous sedimentary rocks in southwestern Newfoundland and their relations to similar strata in western Cape Breton Island. Canadian Mining and Metallurgical Bulletin, 57, pp. 507-520.

BECKER, G. 1980. Ostracoden-Entwicklung im Kantabrischen Variszikum (Nordspanien). Neues Jahrbuch Fur Geologische und Palaeontologie Abhandlungen, 163, pp. 153-163.

-1982. Fazies-aziegende Ostracoden-Vergesellschaftungen aus dem fruhen Oberkarbon des Kantabrischen Gebirge. Neues Jahrbuch Fur Geologische und Palaeontologie Abhandlungen, 164, pp. 307-338.

- 1984. Ostracoden-Faunen thuringischer Proveienz aus dem Karbon des Kantabrischen Gebirge (N-Spanien). Z. dt. Geol.Ges., 135, pp. 317-324.

BECKER, G., BLESS, M.J.M., and KULLMANN, J. 1975. Oberkarbonische Entomozoen-Schiefer im Kantabrischen Gebirge (Nordspanien). Neues Jahrbuch Fur Geologische und Palaeontologie Abhandlungen, 150, pp. 92-110.

BECKER, G., BLESS, M.J.M., STREEL, M., and THOREZ, J. 1974. Palynology and ostracode distribution in the upper Devonian and basal Dinantian of Belgium and their dependence upon sedimentary facies. Mededelingen Rijks Geologische Dienst. Nieuwe Serie, 25, pp. 9-99.

BELL, W.A. 1927. Outline of Carboniferous stratigraphy and geologic history of the Maritime Provinces of Canada. Trans, Roy. Soc. Can., Series 3, 2, pp. 75-108.

- 1929. Horton-Windsor district, Nova Scotia. Canada Department of Mines, Geological Survey, Memoir 155, 268 p.

- 1948. Early Carboniferous strata of St. Georges Bay area, Newfoundland. Canada Department of Mines and Resources, Geological Survey Bulletin, 10,45 p.

- 1960. Mississippian Horton Group of type Windsor-Horton Districh, Nova Scotia. Geological Survey of Canada, Memoir 314, $112 \mathrm{p}$.

BLESS, M.J.M. 1983. Late Devonian and Carboniferous ostracode assemblages and their relationship to the depositional environment. Geologie, 92, pp. 31-53.

BLESS, M.J.M. and JORDAN, H. 1971. The new genus Copelandella 
from the Carboniferous - the youngest known beyrichiacean ostracodes. Lethaia, 4, pp. 185-190.

BLESS, M.J.M. and POLLARD, J.E. 1973. Paleoecology and ostracode faunas of Westphalian ostracode bands from Limburg, the Netherlands and Lancashire, Great Britain. Mededelingen Rijks Geologische Dienst. Nieuwe Serie, 24, pp. 21-53.

BRADLEY, D.C. 1982. Subsidence in Late Paleozoic basins in the northem Appalachians. Tectonics, 1, pp. 107-123.

COPELAND, M.J. 1957. The arthropod fauna of the upper Carboniferous of the Maritime Provinces. Geological Survey of Canada, Memoir 286, $110 \mathrm{p}$.

CRASQUIN, S. 1984. L'ecozone a Bairdiacea et Paraparchitacea (Ostracoda) au Dinantien. Geobios, 17, fasc.3, pp. 341-348.

DAWSON, J.W. 1868. Acadian Geology. Macmillan and Company Limited, London, 2nd edition, 694 p.

- 1879. Note on Carboniferous Entomostraca from Nova Scotia, in the Peter Redpath Museum, determined and described by Professor T.R. Jones, F.R.S. and Mr. Kirkby. Can. Rec. Sci., 7, pp. 316323.

DEWEY, C.P. 1983a. The taxonomy and palaeoecology of lower Carboniferous ostracodes and peracarids (Crustacea) from southwestern Newfoundland and central Nova Scotia. Unpublished Ph.D. dissertation, Memorial University of Newfoundland, 383 p.

. 1983b. Ostracode palaeoecology of the Lower Carboniferous of western Newfoundland. In Application of Ostracoda. Edited by R.F. Maddocks. University of Houston, pp. 104-115.

- 1985. The palaeobiogeographic significance of Lower Carboniferous crustaceans (ostracodes and peracarids) from westem Newfoundland and central Nova Scotia, Canada. Palaeogeography, Palaeoclimatology and Palaeoecology, 49, pp. 175-188.

- 1987. Palaeoecology of a hypersaline Carboniferous ostracod fauna. Jour. Micropalaeontology, 6, pp. 29-33.

1988. Lower Carboniferous ostracode assemblages from Nova Scotia. In Evolutionary biology of ostracoda. Edited by T. Hanai, N. Ikeya, and K. Ishizaki. Developments in Palaeontology and Stratigraphy, 11, Elsevier, Amsterdam, pp. 685-696.

DEWEY, C.P. and FAHRAEUS, L.E. 1987. Taxonomy of Ostracoda (Crustacea) from Mississippian strata of Maritime Canada. Geologica et Palaeontologica, 21, pp. 93-135.

DIX, G.R. 1982. The Codroy Group (Upper Mississippian) on the Port au Port Peninsula, western Newfoundland: stratigraphy, paleontology, sedimentology and diagenesis. Unpublished M.Sc. thesis, Memorial University of Newfoundland, $219 \mathrm{p}$.

DIX, G.R. and JAMES, N.P. 1987. Late Mississippian bryozoan/ microbial build-ups on a drowned karst terrain: Port au Port Peninsula, westem Newfoundland. Sedimentology, 34, pp. 779. 793.

FERGUSON, L. 1962. The palaeoecology of a lower Carboniferous marine transgression. Journal of Paleontology, 36, pp. 1009-1107.

1974. The palaeoecological and taxonomic significance of growth series of the ostracode genera Bairdia and Paraparchites from a Scottish lower Carboniferous shale. Geological Society of America, Abstract with Programs, p. 732.

GELDSETZER, H.H.J., GILES, P., MOORE, R., and PALMER, W. 1980. Trip 22: stratigraphy, sedimentology and mineralisation of the Carboniferous Windsor Group, Nova Scotia. Geological Association of Canada Annual Meeting, Halifax, Nova Scotia, Field Trip Guide, 42 p.

GILES, P.S. 1981. Major transgressive-regressive cycles in middle to late Visean rocks of Nova Scotia. Department of Mines and Energy, Halifax, Nova Scotia, Paper 81-2, 27 p.

GILES, P.S., BOEHNER, R.C., and RYAN, B.J. 1979. Carbonate banks of the Gays River Formation in central Nova Scotia. Department of Mines and Energy, Halifax, Nova Scotia, Paper 79-7, 57 p.

HAACK, R.C. and KAESLER, R.L. 1980. Upper Carboniferous ostracode assemblages from a mixed carbonate-terrigenous-mud environment. Lethaia, 13, pp. 147-156.

HOWIE, R.D. and BARSS, M.S. 1975. Upper Paleozoic rocks of the Atlantic Provinces, Gulf of St. Lawrence and adjacent continental shelf. Geological Survey of Canada, Paper 74-30, pp. 35-51.

JONES, T.R. and KIRKBY, J.W. 1884. On some Carboniferous Entomostraca from Nova Scotia. Geological Magazine, New Series, 1, pp. 356-362.

1889. On some ostracodes from the Mabou Coalfield, Inverness County, Cape Breton (Nova Scotia). Geological Magazine, New Series, 6, pp. 296-271.

KAESLER, R.L. 1982. Ostracoda as environmental indicators in Late Pennsylvanian subsurface shales. Third North American Paleontol. Conv., Procs., 1, pp. 275-280.

KNIGHT, I. 1983. Geology of the Carboniferous Bay St. George Subbasin, westem Newfoundland. Department of Mines and Energy, St. John's, Newfoundland, Memoir 1, 358 p.

KORNICKER, L.S. 1961. Ecology and taxonomy of Recent Bairdiinae (Ostracoda). Micropaleontology, 7, pp. 55-70.

LETHIERS, F. and CRASQUIN, S. 1987. Reconnaissance des milieux profonds de la Paleotethys a l'aide des ostracodes. Bull. Soc. Geol. France, 3, pp. 415-423.

LEVINTON, J.S. 1970. The paleoecological significance of opportunistic species. Lethaia, 3, pp. 69-78.

MELNYK, D.H. and MADDOCKS, R.F. 1988. Ostracode biostratigraphy of the Permo-Carboniferous of central and north-central Texas, Part 1: Paleoenvironmental framework. Micropaleontology, 34, pp. 1-20.

MOORE, R.G. 1967. Lithostratigraphic units in the upper part of the Windsor Group, Minas sub-basin, Nova Scotia. In Geological Association of Canada Special Paper No. 4. Edited by E.R.W. Neale and H. Williams. Pp. 245-266.

POLLARD, J.E. 1966. A non-marine ostracod fauna from the Coal Measures of Durham and Northumberland. Palaeontology, 9, pp. 667-697.

- 1969. Three ostracode-mussel bands in the Coal Measures (Westphalian) of Northumberland and Durham. Procs. Yorks. Geol. Soc., 37, pp. 239-276.

ROBINSON, E. 1978. The Carboniferous. Geological Journal, Special Issue No. 8, Seel House Press, Liverpool, pp. 121-166,

SCHENK, P.E. 1969. Carbonate-sulfate-redbed facies and cyclic sedimentation of the Windsorian Stage (middle Carboniferous), Maritime Provinces. Canadian Joumal of Earth Science, 6, pp. 1037-1065.

SOHN, I.G. 1971. New Late Mississippian ostracode genera and species from northern Alaska. United States Geological Survey, Professional Paper 711-A, 24 p.

VAN AMERON, H.W., BLESS, M.J.M., and WINKLER PRINS, C.F. 1970. Some paleontological and stratigraphical aspects of the Upper Carboniferous Sama Formation (Asturias, Spain). Mededelingen Rijks Geologische Dienst, Nieuwe Serie, 21, pp. 9-79.

VAN DE POLL, H.W. 1978. Palaeoclimatic control and stratigraphic limits of synsedimentary mineral occurrences in Mississippian early Pennsylvanian strata of eastern Canada. Economic Geology. 73, pp. 1069-1081.

VAN DER ZWAN, C.J. 1981. Palynology, phytogeography and climate of the lower Carboniferous. Palaeogeography, Palaeoclimatology and Palaeoecology, 33, pp. 279-310.

VON BITTER, P.H., SCOTT, S.D., and SCHENK, P.E. 1988. Hy- 
drothermal vent animals in carbonate mounds in bacterial laminites, Lower Codroy Group (Lower Carboniferous), Port au Port
Peninsular, Newfoundland, Canada. Geological Association of Canada, Annual Meeting, Abstract with Programs, 13, p. A130. 